\title{
PERBANDINGAN SISTEM HUKUM COMMON LAW, CIVIL LAW DAN ISLAMIC LAW DALAM PERSPEKTIF SEJARAH DAN KARAKTERISTIK BERPIKIR
}

\author{
Farihan Aulia, Sholahuddin Al-Fatih \\ Direktorat Jenderal Imigrasi, Kementerian Hukum dan HAM Wilayah Jawa Timur \\ Fakultas Hukum Universitas Muhammadiyah Malang \\ J1. Kayon, No. 50-52, Genteng, Surabaya \\ Jl. Raya Tlogomas, No. 246, Dau, Malang \\ Email : salfatih@umm.ac.id
}

\begin{abstract}
The legal system or commonly referred to as the legal tradition, has a wealth of scientific treasures that can be examined in more depth through a holistic and comprehensive comparative process. Exactly, the comparison of the legal system must accommodate at least three legal systems that are widely used by countries in the world today. The three legal systems are the Continental European legal system, Anglo American and Islamic Law. The comparative study of the three types of legal systems found that the history of the Continental European legal system is divided into 6 phases, while Anglo American legal history began in the feudalistic era of England until it developed into America and continues to be studied until now. Meanwhile, the history of Islamic law is divided into 5 phases, starting from the Phase of the Prophet Muhammad to the Resurrection Phase (19th century until nowadays). In addition to history, the authors find that the Continental European legal system has the characteristic of anti-formalism thinking, while the Anglo American legal thinking characteristic tends to be formalism and is based on a relatively primitive mindset. While the thinking character of Islamic Law is much influenced by the thought of the fuqoha (fiqh experts) in determining the law to solve a problem, so relatively dynamic and moderate.
\end{abstract}

\section{Keywords: Comparative, Legal Systems, History, Character of Thinking}

\begin{abstract}
Abstrak
Sistem hukum atau lazim pula disebut sebagai tradisi hukum, memiliki kekayaan khazanah keilmuan yang bisa ditelisik secara lebih mendalam melalui proses perbandingan yang holistik dan komprehensif. Tentunya, perbandingan sistem hukum tersebut minimal harus mengakomodasi tiga sistem hukum yang banyak digunakan oleh negara-negara di dunia saat ini. Ketiga sistem hukum tersebut adalah sistem hukum Eropa Kontinental, Anglo Amerika dan Hukum Islam. Hasil studi perbandingan terhadap keiga jenis sistem hukum tersebut menemukan bahwa sejarah sistem hukum Eropa Kontinental terbagi menjadi 6 fase, sedangkan sejarah hukum Anglo Amerika dimulai di era feodalistik Inggris hingga berkembang ke Amerika dan terus dipelajari hingga sekarang. Sementara itu sejarah hukum Islam terbagi menjadi 5 fase, mulai dari Fase Rasulullah Muhammad SAW hingga Fase Kebangkitan (abad ke-19 sampai sekarang). Selain sejarah, penulis menemukan bahwa sistem hukum Eropa Kontinental memiliki karakteristik berpikir anti formalisme, sementara itu karakteristik berpikir hukum Anglo Amerika cenderung formalisme dan menginduk pada pola pikir yang masih relatif primitif. Sedangkan karakteristik berpikir Hukum Islam banyak
\end{abstract}


dipengaruhi oleh pemikiran para fuqoha (ahli fiqh) dalam menentukan hukum untuk memecahkan suatu masalah, sehingga relatif dinamis dan moderat.

\section{Kata Kunci : Perbandingan, Sistem Hukum, Sejarah, Karakter Berpikir}

\section{A. PENDAHULUAN}

Studi perbandingan hukum akan kurang menarik jika tanpa melibatkan unsur-unsur yang melekat dari masing-masing keluarga sistem hukum. Sistem hukum atau lazim pula disebut tradisi hukum, memiliki kekayaan khazanah keilmuan yang bisa ditelisik secara lebih mendalam melalui proses perbandingan yang holistik dan komprehensif. Pembedaan tersebut dilakukan dengan melihat atau menilai karakter tertentu dari masing-masing sistem hukum, misalnya terkait ideologi, letak geografis, persamaan sejarah, suku atau ras, sumber hukumnya, intitusi atau lembaga hukum yang unik dan sebagainya. Kekhasan itulah yang menjadi pembeda, yang oleh para ilmuwan dijadikan sebagai obyek penelitian. Misalnya jika melihat sistem hukum Eropa Kontinental, maka yang terlintas dalam benak adalah mereka memiliki karakter anti formalism, berkebalikan dengan sistem hukum Anglo Amerika. Anglo Amerika lebih berkarakter secara formalism, seperti yang kebanyakan terjadi dalam system hukum primitif atau hukum-hukum terdahulu.

Perbedaan yang lain juga bisa ditemukan dalam sistem hukum Islam. Hukum Islam merupakan bagian dari keluarga sistem hukum, yang berasal dari ajaran agama Islam. Hukum Islam bersumber dari Al-Qur'an, Al-Hadits serta Ijtihad (kesepakatan para ulama untuk menetapkan hukum atas suatu perkara yang dilandaskan pada dalil syara'). Jika ditinjau dari bentuknya, hukum islam bisa berupa ketentuan tertulis maupun ketentuan tidak tertulis. Ketentuan tertulis seperti halnya yang terdapat dalam Al-Qur'an, atau jika melihat pada produk hukum nasional, kita bisa merujuk pada Kompilasi Hukum Islam (KHI) atau juga perda syariat yang berlaku di Aceh. Sedangkan untuk ketentuan tidak tertulis, hukum islam memiliki beberapa instrumen yang dianut oleh masyarakat tertentu layaknya hukum adat, seperti konsep pembagian waris di masyarakat Minangkabau. Secara umum, hukum islam membagi pokok bahasannya menjadi dua aspek besar, yakni aspek ibadah (hubungan dengan Allah) dan juga aspek muamalah (hubungan dengan sesama manusia).

Sistem hukum Islam mengenal lima kaidah hukum yang digunakan untuk mengatur aspek ibadah ataupun muamalah. Kelima kaidah tersebut biasa disebut dengan Al Ahkam AlKhomsah atau lima penggolongan hukum yang lima, meliputi : mubah, sunnah, wajib, makruh dan haram. ${ }^{1}$ Kelima jenis penggolongan tersebut bisa juga disebut sebagai hukum taklifi. Mubah berarti kebolehan, sunnah berarti apabila dilakukan mendapatkan pahala, jika ditinggalkan tidak mendapatkan apa-apa. Sedangkan wajib berarti harus dilakukan, bila ditinggalkan mendapatkan dosa. Sementara makruh jika dilakukan akan memberikan kerugian bagi pelaku dan orang disekitarnya. Haram merupakan larangan, jika dikerjakan akan

\footnotetext{
${ }^{1}$ Tim Penyusun, Islam Untuk Disiplin Ilmu Hukum, Jakarta: Ditjen Kelembagaan Agama Islam, Departemen Agama, Agustus 2002, h 16. Lihat juga Mohammad Daud Ali, Hukum Islam : Pengantar Ilmu Hukum dan Tata Hukum Islam di Indonesia, Jakarta: Raja Grafindo Persada, 1996, h 44
} 
mendapatkan dosa. Selain hukum taklifi, dikenal pula hukum wadhi'. Hukum wadhi' merupakan hukum yang mengandung sebab, syarat dan halangan terjadinya hukum dan hubungan hukum. ${ }^{2}$ Untuk lebih jelas mendalami tentang perbedaan yang ada dalam keluarga sistem hukum, khususnya dalam sistem hukum Eropa Kontinental, Anglo Amerika dan hukum Islam, akan dijelaskan lebih lanjut dalam pembahasan berikut. Topik bahasan yang menjadi fokus obyek perbandingan adalah seputar sejarah dan karakteristik berpikir dari masing-masing sistem hukum.

\section{B. PEMBAHASAN}

\section{Perspektif Sejarah}

\section{a. Sejarah Sistem Hukum Eropa Kontinental (Civil Law)}

Hukum Romawi merupakan cikal bakal dari sistem hukum Eropa Kontinental, meskipun hukum Romawi merupakan roh dari sistem hukum Eropa Kontinental, tetapi pengaruh hukum Romawi tersebut juga sangat kuat terasa dalam perkembangan sistem hukum Anglo Saxon. Karena banyak pencipta kaidah dalam sistem hukum anglo saxon sudah terlebih dahulu mempelajari sistem hukum Romawi atau sistem hukum Eropa Kontinental. Dari sana, akhirnya sistem hukum Eropa Kontinental biasa disebut sebagai sistem hukum Romano-Germania, atau juga sering disebut civil law system. ${ }^{3}$ Sistem hukum Eropa Kontinental berkembang di Negara-negara Eropa, seperti Perancis, Jerman, Italia, Swiss, Austria, Negara-negara Amerika Latin, Turki, beberapa Negara Arab, Afrika Utara, dan Madagaskar. ${ }^{4}$ Sistem hukum ini juga meneybar ke Asia karena dibawa oleh para penjajah, seperti Belanda yang akhirnya membuat Indonesia juga memakai sistem hukum ini.

Sistem hukum Eropa Kontinental menggunakan kitab undang-undang atau undangundang sebagai sumber hukum utamanya. ${ }^{5}$ Sekalipun bersumber pada hukum yang tertulis dalam undang-undang yang dibuat oleh lembaga legislatif, dalam beberapa Negara penganut sistem hukum ini, putusan-putusan kadang juga dijadikan sebagai rujukan sumber hukum meskipun hanya sebagai pelengkap dari apa yang telah ada dalam undangundang. Perubahan dan perkembangan hukum dalam sistem hukum Eropa Kontinental pada prinsipnya sangat bergantung pada parlemen. Hal ini yang kemudian menjadikan hukum yang ada pada Negara-negara penganut sistem hukum Eropa Kontinental tidak lepas dari unsur politis yang kuat meskipun juga menjadi lebih teoritis, koheren, dan terstruktur. ${ }^{6}$ Perkembangan sistem Hukum Eropa Kontinental terjadi dalam beberapa fase, yakni : ${ }^{7}$

\section{1) Fase Formasi Hukum Romawi}

\footnotetext{
${ }^{2}$ Mohammad Daud Ali, Ibid, h 45

${ }^{3}$ Munir Fuady, Perbandingan Ilmu Hukum, PT. Refika Aditama, Bandung, 2007, h. 32.

${ }^{4}$ Peter de Cruz, Comparative Law in a Changing World, Cavendish Publishing Limited, London-Sydney, 1999, h. 37.

${ }^{5}$ Munir Fuady, Op.cit., h. 31.

${ }^{6}$ Ibid., h. 34.

${ }^{7}$ Munir Fuady, Op.cit., h. 57-58.
} 
Fase formasi hukum Romawi dimulai sejak berlakunya The Twelve Tables (UndangUndang Dua Belas Pasal) di tahun 450 SM. The Twelve Tables ini diyakini sebagai tonggak pertama hukum Romawi yang merupakan kumpulan peraturan dasar yang terdiri dari adat istiadat Latin dan juga kombinasi beberapa hukum Yunani. The Twelve Tables dibuat oleh komisi khusus yang telah ditunjuk pada saat itu. Akan tetapi The Twelve Tables belum dapat dikatakan sebagai bagian dari legislasi yang definitif dan komprehensif, mengingat substansinya hanya berupa peraturan dasar. Banyak hukum yang belum dituliskan di sini, sehingga membuka ruang intepretasi pemuka gereja Katholik dan ahli hukum. ${ }^{8}$

\section{2) Fase Kematangan Hukum Romawi}

Fase kematangan hukum Romawi terjadi sejak berlakunya Corpus Juris Civilis di abad VI Masehi. Corpus Juris Civilis merupakan kompilasi aturan hukum yang dibuat atas arahan Raja Justinian berupa kodifikasi hukum yang bersumber dari keputusan dan maklumat raja-raja sebelumnya dengan tambahan modifikasi yang disesuaikan dengan kondisi sosial dan ekonomi pada saat itu. ${ }^{9}$ Corpus Juris Civilis terdiri atas beberapa bagian, yaitu:

a) Institute

Sebuah risalah sistematis berupa buku ajar kecil yang dimaksudkan untuk pengantar bagi mereka yang baru belajar hukum.

b) Digest atau Pandect

Digest atau Pandect adalah bagian terpenting dari Corpus Juris Civilis. Bagian ini berisi kompilasi dari beberapa pendapat juris Romawi yang telah disunting, disusun berdasarkan judul atau kategori yang diambil dari zaman klasik sampai dengan abad ke-3 $\mathrm{M}$.

c) Code

Kumpulan aturan hukum termasuk maklumat dan keputusan mulai dari zaman Hadrian yang disusun secara kronologis dalam masing-masing judul agar bisa dilacak evolusi dari sebuah konsep, di mana fakta-fakta dalam sebuah perkara dibedakan dari fakta-fakta yang serupa dalam kasus sebelumnya.

d) The Novels

Kumpulan aturan yang dibuat oleh Justinian sendiri, didasarkan pada koleksi pribadi, dan mulai disebarluaskan antara tahun 553 dan $544 \mathrm{M}$.

Hukum Romawi dalam Corpus Juris Civilis terus berlaku dan berkembang, kecuali beberapa abad setelah jatuhnya kerajaan Romawi. ${ }^{10}$ Sejak jatuhnya kekaisaran Romawi, maka hukum perdata Romawi yang lebih mentah dan disederhanakanlah yang diaplikasikan. Hukum ini terdiri atas gabungan adat istiadat Germanik dan hukum Romawi yang diperuntukkan juga untuk bangsa Jerman dan Romawi. ${ }^{11}$

\footnotetext{
${ }^{8}$ Peter De Cruz, Op.cit., h. 51.

${ }^{9}$ Ibid., h. 53.

${ }^{10}$ Munir Fuady, Op.cit., h. 59.

${ }^{11}$ Peter De Cruz, Op.cit., h. 54.
} 


\section{3) Fase Kebangkitan Kembali Hukum Romawi}

Fase kebangkitan kembali hukum Romawi terjadi sekitar abad XI Masehi. Fase ini memulai diberlakukannya lagi Corpus Juris Civilis setelah sempat vakum sejak runtuhnya kekaisaran Romawi. Corpus Juris Civilis diberlakukan kembali setidaknya karena dua alasan utama, yakni:

a. Adanya konsep Imperium Romawi Suci (Holy Roman Empire) dimana Justinian dianggap sebagai raja suci dengan Corpus Juris Civilis sebagai legislasi imperiumnya.

b. Pengakuan dari banyak ahli yang menyatakan bahwa Corpus Juris Civilis sebagai kitab hukum yang sangat berkualitas. ${ }^{12}$

Hukum Romawi berkembang di universitas-universitas di Bologna Italia yang kemudian menjadi rujukan pembelajaran hukum di seluruh penjuru Eropa. Di universitas-universitas tersebut kemudian lahir kelompok-kelompok ahli hukum, di antaranya yang terkenal adalah Glossator dan Commentator. Glossator adalah kelompok sarjana yang pertama kali berinisitaif untuk mempelajari hukum Romawi secara sistematik dengan menganalisis teks-teks individual dari Corpus Juris Civilis dan berusaha merekonsiliasikannya secara logis dengan teks-teks lainnya. Sedangkan Commentator adalah kelompok yang lahir setelah Glossator yang memberikan ulasanulasan terkait teks Corpus Juris Civilis secara sistematis dan sintesis. ${ }^{13}$ Hukum Romawi versi Glossator dan Commentator kemudian dikenal dengan istilah Jus Commune. Akan tetapi terbentuknya Jus Commune tidak hanya dipengaruhi oleh adanya Corpus Juris Civilis, tapi juga hukum Kanonik (gerejawi). Hal ini terjadi karena sebelum kebangkitan kembali hukum Romawi, hukum kanonik ini juga berlaku bahkan telah tertulis secara baik. ${ }^{14}$

\section{4) Fase Resepsi Hukum Romawi}

Fase resepsi hukum Romawi dimulai sekitar abad XVI Masehi sejak hukum Romawi khususnya Jus Commune diberlakukan di seluruh penjuru Eropa. Pusat pendidikan hukum pada abad XVI dan XVII berpindah dari Prancis ke Belanda. Di Belanda ini muncul kelompok The Humanist yang mengembangkan kajian aliran hukum alam modern. The Humanist menggunakan teknik kajian sejarah dan filosofi sehingga Corpus Juris Civilis hanya dipandang sebagai bahan sejarah saja. Akan tetapi hasil kajian para ahli hukum di Belanda ini mampu mengembangkan sistem hukum yang sistematis sebagai suatu hukum alam yang berlaku universal. ${ }^{15}$

\section{5) Fase Kodifikasi Hukum}

Fase kodifikasi hukum terjadi ketika dibuatnya beberapa kodifikasi di berbagai Negara. Salah satu kodifikasi yang terkenal adalah Code Napoleon di Perancis. Fase kodifikasi ini merupakan imbas dari aliran hukum alam yang membangkitkan

\footnotetext{
${ }^{12}$ Munir Fuady, Op.cit., h. 60-61.

${ }^{13}$ Peter De Cruz, Op,cit., h. 55-56.

${ }^{14}$ Munir Fuady, Op.cit., h. 61-62.

${ }^{15}$ Ibid.
} 
semangat kodifikasi sebagai upaya untuk mempertahankan sejumlah peraturan dan prinsip yang konsisten secara logis. ${ }^{16}$

\section{6) Fase Resepsi Kodifikasi}

Fase resepsi kodifikasi terjadi tidak lama setelah berlakunya Code Napoleon di Perancis. Beberapa Negara di Eropa bahkan di benua lain mulai memberlakukan Code Napoleon dengan beberapa perubahan dan penyesuaian. Di Belanda misalnya, pada tahun 1838 mulai diberlakukan Burgerlijke Wetboek yang merupakan kodifikasi hukum perdata. ${ }^{17}$

Fase Kematangan Hukum Romawi terjadi pada saat mulai berlakunya kumpulan undang-undang yang sangat spektakuler di Romawi, yakni saat dimulainya Civil Law sebagai sebuah sistem hukum yang otonom, lahir dan berkembang di Eropa Kontinental serta pengaruh kolonialisasi. Sistem hukum ini senantiasa mengalami perkembangan, perubahan, atau menjalani suatu evolusi. Selama evolusi ini, ia mengalami penyempurnaan yaitu menyesuaikan kepada tuntutan dan kebutuhan masyarakat yang berubah. Pengkajian hukum Romawi di universitas, menjadikan hukum Romawi sebagai hukum yang dimodernisasi untuk menghadapi zamannya. Dalam pengkajian ini, didominasi oleh pemikiran mazhab hukum alam. Sistem hukum Eropa Kontinental cenderung aksiomatik kepada hukum yang dibuat secara sadar oleh manusia atau hukum perundang-undangan. Sistem hukum ini mula-mula berlaku di daratan eropa barat yaitu di Jerman kemudian ke Prancis dan selanjutnya ke Belanda kemudian di negara-negara sekitarnya. Belanda yang pernah menjajah bangsa Indonesia membawa sistem hukum ini dan memberlakukannya di seluruh wilayah jajahannya (asas konkordasi).

\section{b. Sejarah Sistem Hukum Anglo Amerika (Common Law)}

Sistem hukum Anglo Amerika atau common law system diterapkan dan mulai berkembang sejak abad ke-16 di negara Inggris. Di dukung keadaan geografis serta perkembangan politik dan sosial yang terus menerus, sistem hukum ini dengan pesat berkembang hingga di luar wilayah Inggris, seperti di Kanada, Amerika, dan negaranegara bekas koloni Inggris (negara persemakmuran/ commonwealth). ${ }^{18}$ Dalam sistem ini tidak dikenal sumber hukum baku seperti halnya di Civil law. Sumber hukum tertinggi hanyalah kebiasaan masyarakat yang dikembangkan di pengadilan / telah menjadi keputusan pengadilan. Sumber hukum yang berasal dari kebiasaan inilah yang kemudian menjadikan sistem hukum ini disebut common law system atau unwritten law (hukum tidak tertulis).

Sejarah hukum common law dimulai dari tahun 1066 ketika sistem pemerintahan di Inggris bersifat feodalistis, dengan melakukan pembagian wilayah yang dikuasakan ke tangan Lord dan rakyat harus menyewanya kepada Lord tersebut. Kekuasaan Lord yang

\footnotetext{
${ }^{16}$ Peter De Cruz, Op.cit., h. 58-59.

${ }^{17}$ Munir Fuady, Op.cit., h. 58.

${ }^{18}$ Peter De Cruz, Op.Cit., h. 142.
} 
semakin besar menyebabkan ia dapat membentuk pengadilan sendiri yang dinamakan dengan minoral court. Pengadilan ini menjalankan tugasnya berdasarkan hukum kebiasaan setempat dan hukum yang ditetapkan oleh Lord sendiri. Akibatnya muncul kesewenangan dan berbagai penyelewengan yang juga melahirkan pemberontakanpemberontakan hingga akhirnya tercium oleh Raja Henry II (1154-1180). Kerajaan Inggris lantas berinisiatif mengambil beberapa kebijaksanaan, yaitu : ${ }^{19}$

1) Disusunnya suatu kitab yang memuat hukum Inggris pada waktu itu. Agar mendapatkan kepastian hukum kitab tersebut ditulis dalam bahasa latin oleh Glanvild chief justitior dari Henry II dengan judul Legibus Angliae;

2) Diberlakukannya writ system, yakni surat perintah dari raja kepada tergugat agar membuktikan bahwa hak-hak dari penggugat itu tidak benar. Dengan demikian tergugat mendapat kesempatan untuk membela diri;

3) Diadakannya sentralisasi pengadilan (Royal Court) yang tidak lagi mendasarkan pada hukum kebiasaan setempat melainkan pada Common Law, yang merupakan suatu unifikasi hukum kebiasaan yang sudah diputus oleh hakim (yurisprudensi). Hal ini menjadi langkah besar bagi kemajuan hukum di Inggris pada masa itu.

Akibat banyaknya perkara dan keterbatasan Royal Court dan sistem writ dalam mengadili, maka penduduk Inggris kemudian mencari keadilan kepada pimpinan gereja atau Lord of chancellor. Pengadilan yang dilakukan oleh pimpinan gereja menurut sistem hukum Inggris tidaklah bertentangan, karena pada saat itu pengadilan Royal Court didasarkan pada common law dan hakim-hakimnya bertindak atas nama raja (fons iustitiae atau raja selaku sumber keadilan dan kelayakan). Sedangkan pengadilan Court of Chancery didasarkan pada hukum gereja atau hukum kanonik dan hakimnya adalah seorang rohaniawan. Sistem penyelesaian perkara di pengadilan ini dikenal sebagai sistem equity, yakni sistem penyelesaian perkara yang didasarkan pada hukum alam (ketuhanan) atau keadilan.

Dengan semakin banyaknya minat dari masyarakat untuk mencari keadilan kepada Lord of Chancellor menyebabkan terbentuknya pengadilan tersendiri yaitu Court of Chancerry di samping Royal Court yang telah ada. Untuk keselarasan, maka pengadilan Inggris melakukan reorganisasi (judicature act) pada tahun 1873-1875, yaitu meletakkan satu atap pengadilan Royal Court dan Court of Chancerry. Penyelesaian-penyelesaian perkara tidak lagi berbeda, yakni perkara-perkara Common Law (cases at Common Law) maupun perkara-perkara Equity (cases at Equity) sama-sama diajukan ke salah satu pengadilan tersebut. ${ }^{20}$

Keunikan atau kekhasan tatanan hukum Inggris adalah peranan penting yang dimainkan oleh Juri di dalam institusi peradilan. Asal mulanya sistem ini dapat ditelusuri kembali sampai periode kedua abad XII, dengan kata lain sampai periode yang sama dengan terbentuknya common law. Juri di dalam perkara-perkara hukum baru terbentuk sebagai akibat sederetan tindakan untuk menghindari apa yang disebut "godsoordelen"

19 Tanpa Pengarang, The Common and Civil Law Tradition, 2010, The Robbins Collection (Educational use only), Oxford, h. 3-4

${ }^{20}$ Peter De Cruz, Op.cit, h. 142 
atau putusan-putusan kehendak Tuhan atau setidak-tidaknya menghapuskannya. Pada tahun 1166 raja misalnya telah mengeluarkan writ baru, ialah writ of novel disseisin, dimana ia memerintahkan sherrif untuk mengumpulkan dua belas orang dari daerah tertentu untuk menerangkan di bawah sumpah apakah pemegang kekuasaan atas sebidang tanah secara keliru dan tanpa vonis telah mengeluarkan pihak penggugat dari tanah tersebut. Dengan demikian telah dicegah atau dikurangi terjadi duel peradilan di dalam kebanyakan proses di sana.

Hampir bersamaan dengan hal itu maka penuntut umum di dalam perkara-perkara pidana diganti oleh sebuah jury. Jury ini, yang kemudian disebut grand jury, terdiri dari 23 orang yang telah diangkat sumpah dari setiap County (distrik), 12 yang diangkat sumpah dari tiap 100 orang yang harus mengajukan tuntutan (indictment) terhadap kejahatan-kejahatan tersebut (pembunuhan, pencurian dan sebagainya) orang-orang yang diangkat sumpah tersebut harus memutuskan berdasarkan pengetahuan mereka sendiri atas perkara ini dan juga mengenai apa yang menjadi buah mulut orang-orang di daerah yang bersangkutan. Mereka tidak boleh mengumpulkan bahan-bahan bukti. Hal yang disebut terakhir ini adalah tugas sebuah juri kedua, yang disebut petty jury yang selaku demikian terdiri dari dua belas "boni homines" (orang laki-laki yang baik), yang diangkat sumpah dipilih dari warga negara setempat. Juri mencapai vonis melalui evaluasi pengetahuan lokal yang umum, tidak harus melalui penyajian bukti, faktor pembeda dari sistem pengadilan civil law.

Henry II mengembangkan sendiri praktik pengiriman hakim dari pengadilan pusat untuk mendengar berbagai perselisihan di seluruh negeri. hakim akan menyelesaikan sengketa secara ad hoc sesuai dengan apa yang mereka tafsirkan. hakim raja kemudian akan kembali ke London dan membahas kasus mereka dan keputusan yang mereka buat dengan hakim lainnya. Keputusan ini akan dicatat dan diajukan. Dalam waktu, aturan, yang dikenal sebagai stare decisis (juga dikenal sebagai preseden) dikembangkan, dimana hakim akan terikat untuk mengikuti keputusan hakim sebelumnya, dia diperlukan untuk mengadopsi interpretasi sebelumnya hakim hukum dan menerapkan prinsip-prinsip yang sama diumumkan oleh hakim sebelumnya jika dua kasus harus fakta mirip satu sama lain. Setelah hakim mulai menganggap keputusan masing-masing menjadi preseden yang mengikat, sistem pra-Norman dari adat istiadat setempat dan hukum yang berbeda-beda di setiap wilayah digantikan oleh sistem yang (setidaknya dalam teori, meskipun tidak selalu dalam prakteknya) umum di seluruh keseluruhan negara, maka nama "common law." ${ }^{21}$

Pada perkembangan modern, hukum Inggris juga menciptakan ketentuan pengadilan tertulis prerogatif (certiorari, mandamus dan Prohibition) yang memungkinkan diajukannya keberatan terhadap keputusan administratif dari organ dan pejabat negara, yang dengan demikian tidak perlu menciptakan suatu pengadilan administratif tersendiri. ${ }^{22}$ Di Amerika, orang-orang Inggris yang pertama kali membawa hukum common law dikarenakan mereka menggunakan hukum yang paling akrab dengan mereka. Pada saat itu, banding dari pengadilan koloni masih tetap ditujukan ke London, tetapi pengadilan

\footnotetext{
${ }^{21}$ J.H. Baker, An Introduction to English Legal History, London, 2002, h. 16-17

${ }^{22}$ Peter De Cruz, Op.cit, h. 143
} 
gereja tidak pernah didirikan di koloni orang Inggris di Amerika. Sampai dengan tahun 1776, sistem common law Inggris masih menjadi dasar dari sistem hukum di 13 koloni di Amerika. Namun, prinsip common law Inggris hanya diaplikasikan hanya apabila tidak bertentangan dengan kondisi konstitusional, politik atau geografis dari negara bagian yang baru. $^{23}$

Meskipun Amerika Serikat dan kebanyakan negara persemakmuran mewarisi tradisi common law dari sistem hukum Inggris, hukum Amerika cenderung unik dalam banyak hal. Ini disebabkan karena sistem hukum Amerika terputus dari sistem hukum Britania akibat revolusi kemerdekaan dan setelah itu ia berkembang secara mandiri dari sistem hukum Persemakmuran Britania. Oleh karena itu, apabila kita mencoba menelusuri perkembangan prinsip-prinsip common law yang tradisional dibuat oleh para hakim, artinya, sejumlah kecil hukum yang belum dibatalkan oleh hukum-hukum yang lebih baru, maka peradilan peradilan Amerika akan melihat kepada kasus-kasus di Britania hanya sampai ke awal abad ke-19. Pengadilan-pengadilan dari berbagai negara Persemakmuran seringkali saling mempengaruhi sesamanya melalui keputusan-keputusan yang diambilnya. Bahkan, pengadilan-pengadilan Amerika jarang sekali mengikuti keputusan-keputusan Persemakmuran pasca-revolusi kecuali apabila tidak ada keputusan yang diambil di Amerika mengenai masalah terkait, fakta-fakta dan hukum yang dimaksud hampir identik, dan alasannya dianggap sangat meyakinkan. Kasus-kasus Amerika yang paling awal, bahkan setelah revolusi, seringkali mengutip kasus-kasus Britania yang sezaman, tetapi kutipan-kutipan seperti itu perlahan-lahan menghilang pada abad ke-19 ketika pengadilan-pengadilan Amerika mengembangkan prinsip-prinsipnya sendiri untuk memecahkan masalah-masalah hukum bangsa Amerika. ${ }^{24}$

\section{c. Sejarah Sistem Hukum Islam (Islamic Law)}

Mayoritas para ahli sejarah hukum islam membagi perkembangan hukum islam ke dalam 5 fase, yaitu : a) Fase Rasulullah Muhammad SAW (610-632 M); b) Fase Khulafaur Rasyidin (632-662 M); c) Fase Pembinaan, Pengembangan dan Pembukuan (abad ke-VII sampai X); d) Fase Kelesuan Pemikiran (abad ke-X sampai XIX); dan e) Fase Kebangkitan (abad ke-XIX sampai sekarang). ${ }^{25}$ Fase awal perkembangan hukum islam dimulai dari lahirnya Muhammad di kota Makkah. Muhammad merupakan nabi sekaligus rasul yang dipercaya oleh Allah untuk menyampaikan kebenaran ajaran agama islam, induk dari system hukum islam yang kini dianut oleh banyak bangsa dan Negara di dunia.

\section{1) Fase Rasulullah Muhammad SAW (610-632 M)}

Sebagaimana telah dijelaskan sebelumnya, Muhammad SAW adalah pembawa ajaran agama islam yang dilahirkan di kota Makkah. Sebelum kelahiran Muhammad,

\footnotetext{
23 Rheinstein, International Ensyclopedia of comparative law, dalam Peter De Cruz, Op.Cit. h. 157.

${ }^{24}$ Elizabeth Gaspar Brown, "Frontier Justice: Wayne County 1796-1836," dalam Essays in Nineteenth-Century American Legal History, ed. Wythe Holt, (Westport, CT: Greenwood Press, 1976): h. 686.

${ }^{25}$ Tim Penyusun, Op.cit., h 30. Lihat juga Mohammad Daud Ali, Op.cit., h 153
} 
kota Makkah layaknya wilayah tandus yang banyak menyimpan permasalahan. Kondisi padang pasir dan gurun sahara, sering memicu terjadinya konflik antar suku, terlebih saat mereka menemukan sumber air atau rumput yang bisa dijadikan sebagai sumber kehidupan. Suku-suku disekitar Makkah hidup berdasarkan garis patrilinial, artinya siapa laki-laki terkuat, yang paling bijak dan berpengaruh, maka akan diangkat sebagai kepala suku dan mendapatkan kehormatan yang luar biasa. Patrilinial juga memicu timbulnya paradigm, bahwa wanita hanya dibebani kewajiban tanpa memperoleh hak. Maka tidak heran, jika banyak bayi perempuan yang dikubur hiduphidup pada masa itu karena dianggap akan mendatangkan aib bagi keluarga.

Tak hanya itu saja, masyarakat Makkah saat itu gemar dengan hal-hal negatif. Konflik horisontal hampir terjadi setiap saat, dipicu oleh hal-hal yang kecil. Mereka juga meninggalkan ajaran Tauhid yang dibawa oleh Nabi Ibrahim. Mereka menyembah berhala yang diletakkan disekitar Ka'bah. Bisa dikatakan, keadaan moral masyarakat Makkah saat itu sangatlah memprihatinkan. Dalam kondisi seperti itu, lahirlah Muhammad SAW pada tanggal 12 Rabiul Awwal tahun gajah atau bertepatan dengan tanggal 20 April 571 Masehi. ${ }^{26}$ Muhammad lahir dari ibu bernama Aminah dan ayah bernama Abdullah. Dalam kondisi masih anak-anak, Muhammad harus menjadi seorang yatim piatu, sehingga pengasuhan dilanjutkan oleh kakek beliau, yakni Abdul Muthalib. Muhammad menikah dengan Siti Khadijah di usia 25 tahun. Muhammad beranjak memasuki usia matang dan tersadar akan kondisi kota Makkah. Di usia ke-37, Muhammad memutuskan untuk berkhalwat (menyendiri) di Gua Hira'. Beliau sering melakukannya hingga usia ke-40 tahun. Saat itu pula Allah menurunkan wahyu melalui perantara malaikat Jibril, tepat di bulan Ramadhan tahun 610 Masehi. $^{27}$

Tiga tahun setelah wahyu pertama turun, Allah memerintahkan agar wahyu tersebut disampaikan ke masyarakat luas. Muhammad yang telah mendapatkan julukan Rasulullah SAW, kini mendapatkan tugas untuk memperbaiki akhlaq penduduk Makkah melalui wahyu yang telah diturunkan padanya. Menurut penelitian Prof. Abdul Wahab Khallaf, seorang Guru Besar Hukum Islam di Univeristas Kairo, terdapat klasifikasi ayat-ayat Al-Qur'an yang berbicara terkait hukum, diantaranya ${ }^{28}$ :

a) Hukum Keluarga (Hukum Perkawinan dan Hukum Waris Islam) sebanyak 70 ayat;

b) Hukum Perikatan terdiri dari 70 ayat;

c) Hukum Ekonomi, termasuk Hukum Dagang terdiri dari 10 ayat;

d) Hukum Pidana terdiri dari 30 ayat;

e) Hukum Tata Negara terdiri dari 10 ayat;

f) Hukum Internasional terdiri dari 25 ayat;

g) Hukum Acara dan Peradilan terdiri dari 13 ayat

\footnotetext{
${ }^{26}$ Tim Penyusun, Ibid

${ }^{27}$ Mohammad Daud Ali, Op.cit, h 159

${ }^{28}$ Ibid, h 162-164
} 
Selain sumber hukum islam yang berasal dari Al-Qur'an, Rasulullah dalam memecahkan permasalahan hukum juga mengacu pada pendapat beliau tentang hukum yang berjumlah kurang lebih 4.500 hadits.

\section{2) Fase Khulafaur Rasyidin (632-662 M)}

Setelah Rasulullah wafat, maka berhentilah wahyu yang diturunkan selama kurang lebih 23 tahun melalui perantara malaikat Jibril. Kepemimpinan Islam selanjutnya menjadi amanah para Khalifah. Tercatat, ada 4 Khalifah yang berperan penting pasca wafatnya Rasulullah, yaitu Abu Bakar, Umar bin Khattab, Utsman bin Affan dan Ali bin Abi Thalib. Abu Bakar yang bergelar Ash-Shiddiq (632-634 M), terkenal dengan kehati-hatiannya. Dalam emnerapkan hukum islam, Abu Bakar selalu menjadikan AlQur'an sebagai dasar utama. Jika masalah belum bisa dipecahkan, barulah Abu Bakar mencari sumbernya melalui Hadits. Jika masih belum terpecahkan juga, Abu Bakar mengumpulkan para ulama untuk meminta ijtihad mereka. Fase kepemimpinan Abu Bakar inilah yang menjadi awal mula berlakunya ijtihad dan ijma para ulama untuk menjadi landasan hukum atas suatu perkara.

Atas anjuran dari Umar bin Khattab, Fase kepemimpinan Abu Bakar juga dikenal sebagai pelopor pembentukan panitia penghimpun Al-Qur'an. ${ }^{29}$ Catatan-catatan ayat Al-Qur'an yang ditulis di pelepah kurma, kulit unta dan sejenisnya mulai dikumpulkan. Setelah wafatnya Abu Bakar, panitia tersebut kembali dilanjutkan oleh Umar bin Khattab (634-644 M), khalifah kedua. Umar mencatatkan namanya sebagai pencetus lahirnya tahun hijriyah berdasarkan peredaran bulan. Selain itu, Umar juga terkenal sebagai sosok yang membiasakan shalat sunnah tarawih di bulan Ramadhan. Selain berpedoman pada dua sumber hukum islam (Al-Qur'an dan Hadits), Umar juga menggunakan pemahaman yang mendalam terhadap nash. Beberapa ijtihad yang dilakukan Umar bin Khattab diantaranya terkait konsep talak tiga dan larangan rujuk, zakat tidak diberikan bagi muallaf, hukum mencuri saat musim kelaparan dan larangan menikahi ahlul bait.

Ijtihad Umar yang lainnya adalah mengenai surat yang ia tulis kepada Abu Musa Al-Asy'ari, hakim di Kufah, Irak. Umar berpsean agar dalam mengambil keputusan atas suatu perkara, harus didasarkan pada Al-Qur'an dan Hadits. Jika tidak terdapat dalam keduanya, maka dianjurkan untuk mengqiyaskan (membandingkan) dengan putusan perkara terdahulu. Jika tidak ada putusan perkara terdahulu yang bisa dijadikan rujukan, maka hakim diharuskan memutuskan berdasarkan pendapat hakim, yang paling adil dan diridhai menurut Allah. Sepintas, jika dipahami, cara tersebut mirip dengan konsep yurisprudensi di Negara yang menganut sistem hukum common law. Estafet kepemimpinan Umar setelah belaiu wafat dilanjutkan oleh Usman bin Affan (644-656 M). jasa Usman yang paling dikenang adalah keberhasilannya membukukan Al-Qur'an yang sampai sekarang masih dipakai dengan sebutan Rasmul Usmani. Sebuah panitia yang dibentuk sejak zaman Abu Bakar hingga akhirnya berhasil dibukukan di masa kepemimpinan Usman bin Affan.

${ }^{29}$ Ibid, h 173 
Mushaf Rasmul Usmani inilah yang menjaga otentifikasi Al-Qur'an sampai sekarang. Pasca Usman, pemimpin umat islam diamanahkan kepada Ali bin Abi Thalib (656-662 M). pada masa ini, hukum islam tidak bisa berkembang terlalu luas. Justru yang ada adalah perpecahan diantara Sunni dan Syiah. Secara keseluruhan, sumber hukum yang digunakan pada fase khulafaur rasyidin adalah Al-Qur'an, AlHadits dan Ijtihad (Ijma' dan Qiyas).

\section{3) Fase Pembinaan, Pengembangan dan Pembukuan (abad ke-VII sampai X)}

Fase ini berlangsung sekitar 250 tahun, berada di bawah dua kekhalifahan, yaitu kekhalifahan Umayyah (662-750 M) dan Abbasiyah (750-1258 M) ${ }^{30}$ Pada fase ini muncul para mujtahid yang hasil pemikirannya masih digunakan sampai sekarang. Diantaranya adalah :

a) Abu Hanifah (Al-Nukman ibn Tsabit) : 700-767 M

Beliau lahir di Kufah, Irak. Awalnya beliau belajar ilmu kalam. Suatu saat ada wanita yang bertanya kepadanya tentang hukum dan beliau tidak bisa menjawabnya. Sejak saat itu beliau tertarik untuk mempelajari hukum islam dalam ilmu fiqh. Sumber hukum yang dianut oleh madzhab Hanafi adalah Al-Qur'an, Hadits dan Ar-Ra'yu dengan menggunakan Ijma', Qiyas, Istihsan dan 'Urf sebagai metode penemuan hukum. ${ }^{31}$

b) Malik bin Anas : 713-795 M

Beliau tinggal di Madinah. Hasil karya beliau yang terkenal adalah kitab hadits berjudul Al-Muwatta'. Sumber hukum yang dianut oleh madzhab Maliki adalah Al-Qur'an dan Hadits dengan menggunakan Ijma' penduduk Madinah, Qiyas dan Maslahah Mursalah sebagai metode penemuan hukum. ${ }^{32}$

c) Muhammad Idris Asy-Syafi'i : 767-820 M

Beliau lahir di Ghazah atau Atsqolan dan berguru kepada Imam Malik di Madinah. Belaiu juga belajar ilmu fiqh kepada Abu Hanifah. Karya beliau yang terkenal adalah Ar-Risalah (pengantar dasar-dasar hukum islam) dan Al-Umm (induk). Sumber hukum yang dianut oleh madzhab Syafi'i adalah Al-Qur'an dan Hadits dengan menggunakan Ijma', Qiyas dan Istishab sebagai metode penemuan hukum. ${ }^{33}$

d) Ahmad bin Hambal (Hanbal) : 781-855 M

Beliau lahir di Baghdad, Irak. Beliau mengarang buku berjudul Al-Musnad/AlMasnad. Sumber hukum utamanya adalah Al-Qur'an dan Hadits. Selain itu beliau juga mengambil ijtihad dari para fuqoha terdahulu dalam emnentukan hukum. Salah satu pengikut madzhab Hambali adalah Muhammad bin Abdul Wahab.

${ }^{30}$ Ibid, h 182

${ }^{31}$ Ibid. h 186

${ }^{32}$ Ibid, h 187

${ }^{33}$ Ibid, h 189 
Dasar pemikiran beliau sampai sekarang diakui sebagai sumber hukum resmi Arab Saudi.

\section{4) Fase Kelesuan Pemikiran (abad ke-X sampai XIX)}

Fase ini ditandai dengan pola berpikir dan budaya taqlid. Tidak ada semangat untuk memperbaharui konsep pemikiran hukum Islam. Beberapa faktor penyebab diantaranya adalah karena munculnya Negara-negara baru di kawasan Eropa, Afrika Utara, Timur Tengah dan Asia. Hal ini memicu ketidakstabilan kondisi politik yang juga mempengaruhi penurunan gairah berpikir. ${ }^{34}$ Akhirnya, fase ini menjadi fase stagnan, lesu bahkan bisa disebut kemunduran hukum islam.

\section{5) Fase Kebangkitan (abad ke-XIX sampai sekarang)}

Setelah melalui fase kelesuan dan kemunduran, hukum islam kembali naik daun setelah lahirnya para tokoh seperti Ibnu Taimiyah dan Ibnu Qayyim Al-Jauziyah. Pola pemikiran keduanya melandasi gagasan yang dikembangkan oleh Muhammad bin Abdul Wahab dengan Wahabi-nya. Ide Abdul Wahab kemudian melatarbelakangi gerakan politik Pan Islamisme yang digagas oleh Jamaludin Al-Afghani. Gerakan ini berusaha membangkitkan semangat untuk meraih kemerdekaan dari kolonialisme Negara barat, khususnya di Negara dengan penduduka muslim. Cita-cita gerakan Pan Islamisme kemudian menginspirasi Muhammad Abduh yang dilanjutkan pula oleh muridnya, yaitu Mohammad Rasyid Ridha.

Pola pemikiran mereka akhirnya melatarbelakangi didirikannya organisasi bernama Muhammadiyah, yang didirikan oleh K.H. Ahmad Dahlan di Yogyakarta pada tahun 1912. Selanjutnya, hukum islam mulai menyebar ke berbagai Negara dan mulai dipelajari diberbagai institusi pendidikan ternama di dunia, seperti Universitas Harvard, Universitas London dan sebagainya. Sampai saat ini-pun, mayoritas seluruh perguruan tinggi yang membuka jenjang pendidikan hukum di Indonesia, pasti menyediakan hukum islam sebagai salah satu mata kuliah yang wajib disajikan dalam proses pembelajaran.

\section{KARAKTERISTIK BERPIKIR}

\section{a. Karakteristik Berpikir Sistem Hukum Eropa Kontinental (Civil Law)}

Civil law merupakan sistem hukum yang menggunakan kitab undang-undang atau undang-undang sebagai sumber hukum utama. Hal ini tentu saja mempengaruhi karakteristik berpikir dalam sistem hukum Eropa Kontinental. Adanya peraturan yang telah dibuat terlebih dahulu sebelum adanya kasus menjadikan pola pemikiran yang abstrak, konseptual dan simetris. ${ }^{35}$ Sistem hukum Eropa Kontinental cenderung merencanakan, mensistematiskan, dan mengatur persoalan sehari-hari dengan sekomprehensif mungkin dengan cara membentuk aturan-aturan hukum sebagai produk legislasi. Sistem hukum Eropa Kontinental bertolak pada satu prinsip umum ke prinsip

\footnotetext{
${ }^{34}$ A. Hanafi, Pengantar dan Sejarah Hukum Islam, Jakarta: Bulan Bintang, 1970, h 174-175

${ }^{35}$ Peter De Cruz, Op.cit., h. 38.
} 
umum lainnya. Dalam menangani suatu perkara, hakim akan mencari rujukan aturanaturan yang sesuai dengan perkara yang sedang ditanganinya. Hakim pada sistem hukum Eropa Kontinental harus bersifat aktif dalam menemukan fakta dan cermat dalam menilai alat bukti sehingga dapat memperoleh gambaran yang lengkap dari perkara tersebut. Setelah itu, hakim dapat memilih aturan apa yang tepat diterapkan atas perkara yang ditanganinya.

\section{b. Karakteristik Berpikir Sistem Anglo Amerika (Common Law)}

Sistem hukum Anglo Amerika atau common law Inggris model pemikirannya dengan pendekatan yang konkret dan berdasarkan pada pengadilan, berusaha mengembangkan jawaban-jawaban pragmatis untuk diketengahkan di depan pengadilan. Dalam hal ini, pengadilan common law tidaklah dipimpin oleh sekumpulan majelis hakim sebagaimana dalam sistem hukum civil, akan tetapi hanya dipimpin oleh satu hakim sebagai wasit untuk menemukan jawaban pragmatis tersebut. Perkara menjadi sumber utama dalam common law, oleh karena itu pendekatannya dari perkara menuju perkara. Para lawyers dari common law berfikir dalam ruang lingkup kelompok dan hubungan hukum tertentu mereka sehingga praktisi common law dituntut untuk mengerti kasus-kasus terdahulu bukan dituntut untuk menghafal undang-undang seperti halnya dalam hukum Civil.

Konsekuensi dari perkembangan historis yang dicerminkan di dalam model common law cenderung berimprovisasi, mengkaji perkara untuk preseden yang memungkinkan, yang mungkin mengikat terhadap pemeriksaan di pengadilan saat itu, dan hanya untuk memutuskan untuk melakukan legislasi dalam cara yang terorganisir dan komprehensif apabila wilayah hukum tertentu dinilai membingungkan, tidak jelas atau menciptakan gap dalam hukum. Bahkan ketika undang-undang yang komprehensif telah dikeluarkan, hukum kasus yang mengawalinya sering kali relevan untuk dijadikan sebuah pedoman interpretasi karena penegakan undang-undang tersebut biasanya dipandang sebagai konsolidasi (dan mungkin juga klarifikasi) dari hukum yang ada. Oleh karena itu, undangundang dalam sistem common law biasanya berusaha untuk membangun atau mengembangkan hukum kasus yang sudah ada.

\section{c. Karakteristik Berpikir Sistem Hukum Islam (Islamic Law)}

Hukum Islam menjadikan Al-Qur'an dan Hadits sebagai sumber hukum utamanya. Namun, untuk menunjang kebutuhan zaman, jika kedua sumber tersebut belum mampu menjawab permasalahan yang ada, maka digunakan beberapa metode penemuan hukum yang bisa dijadikan sebagai pola atau karakter berfikir hukum islam, diantaranya :

1) Ijtihad

Kesungguhan berfikir. Biasanya para fuqoha (ahli fiqh) akan menggali sumber hukum dasar, yaitu Al-Qur'an dan Hadits untuk memecahkan masalah yang ada. Proses berfikir tersebut tidak hanya menggali hukum berdasarkan nash, tapi juga 
melihat asbabun nuzul atau sebab diturunkannya suatu ayat atau lahirnya hadits tertentu.

2) Ijma'

Merupakan kesepakatan para ulama maupun fuqoha atas suatu permasalahan. Jika ijtihad hanya dilakukan oleh seorang diri, maka kumpulan para ahli fiqh yang berijtihad atas suatu dalil syara' itulah yang biasa disebut dengan ijma'.

\section{3) Qiyas}

Yaitu upaya membandingkan sumber hukum yang telah ada atau putusan atas perkara yang sama sebelumnya. Hal ini seperti yang telah diamanahkan oleh Umar bin Khattab kepada hakim Abu Musa Al-Asy'ari

4) 'Urf

Merupakan adat kebiasaan yang berlaku di masyarakat tertentu yang sulit dihilangkan dan tidak terlalu menimbulkan mudhorot. Contoh : masyarakat Aceh yang telah memberlakukan Perda Syariah, secara nyata tetap mengkonsumsi daun ganja. Padahal dalam hukum positif Indonesia, ganja merupakan jenis psikotropika yang dilarang. Namun jika melihat 'Urf atau adat kebiasaan setempat, maka penggunaan daun ganja di Aceh dibolehkan, yaitu sebatas untuk sayur dalam jumlah yang sedikit.

5) Maslahah Mursalah

Pola berfikir dalam menentukan hukum islam dengan melihat kemaslahatan bagi masyarakat sekitar. Hal ini sebagaimana dicontohkan oleh Umar bin Khottob saat membebaskan hukuman bagi pencuri di semenanjung Arab saat terjadi kelaparan.

\section{6) Istishab}

Meneruskan hukum yang ada sebelumnya karena tidak terlihat adanya hukum baru yang melarang/menggantikannya. Karakteristik berfikir ini digunakan oleh pengikut madzhab Syafi'i.

\section{PENUTUP}

Berdasarkan pembahasan diatas, dapat disimpulkan bahwa sejarah sistem hukum Eropa Kontinental terbagi menjadi 6 fase, yaitu : a) Fase Formasi Hukum Romawi; b) Fase Kematangan Hukum Romawi; c) Fase Kebangkitan Kembali Hukum Romawi; d) Fase Respesi Hukum Romawi; e) Fase Kodifikasi; dan f) Fase Resepsi Kodifikasi. Sedangkan sejarah hukum Anglo Amerika dimulai di era feodalistik Inggris hingga berkembang ke Amerika dan terus dipelajari hingga sekarang. Sementara itu sejarah hukum Islam terbagi menjadi 5 fase, yaitu : a) Fase Rasulullah Muhammad SAW (610-632 M); b) Fase Khulafaur Rasyidin (632-662 M); c) Fase Pembinaan, Pengembangan dan Pembukuan (abad ke-7 sampai 10); d) Fase Kelesuan Pemikiran (abad ke-10 sampai 19); dan e) Fase Kebangkitan (abad ke-19 sampai sekarang). 
Selain sejarah, pembahasan diatas juga menyimpulkan bahwa karakteristik berpikir sistem hukum Eropa Kontinental adalah anti formalisme, dengan memberikan suatu wadah dimana substansi akan berbentuk terbuka ujung. Sementara itu karakteristik berpikir hukum Anglo Amerika cenderung formalisme dan menginduk pada pola pikir yang masih relatif primitif. Terakhir adalah karakteristik berpikir hukum islam yang terdiri dari 6 jenis, yaitu : a) Ijtihad; b) Ijma'; c) Qiyas; d) 'Urf; e) Maslahah Mursalah; dan f) Istishab. Karakteristik berpikir tersebut dipengaruhi oleh pemikiran para fuqoha (ahli fiqh) dalam menentukan hukum untuk memecahkan suatu masalah.

\section{DAFTAR PUSTAKA}

Ahmed, Shoayb. 2005. The Development Of Islamic Jurisprudence (Fiqh) And Reason For Justice Dissagreement Among School ff Law. Dissertation: University of South Africa.

Ali, Mohammad Daud, 1996, Hukum Islam : Pengantar Ilmu Hukum dan Tata Hukum Islam di Indonesia, Jakarta: Raja Grafindo Persada

Ali, Zainuddin. 2006. Hukum Islam Pengantar Ilmu Hukum Islam di Indonesia. Jakarta: Sinar Grafika.

Baker, J.H. 2002. An Introduction to English Legal History. Oxford: Oxford University Press.

De Cruz, Peter, 1999, Comparative Law in a Changing Word, 1999, London-Sydney: Cavendish Publishing Limited

De Cruz, Peter. 1999. Perbandingan Sistem Hukum. Bandung: Nusa Media.

Fuady, Munir, Perbandingan Ilmu Hukum, 2010, Bandung: PT. Refika Aditama

Gaspar Brown, Elizabeth, 1976, "Frontier Justice: Wayne County 1796-1836," dalam Essays in Nineteenth-Century American Legal History, ed. Wythe Holt, Westport, CT: Greenwood Press

Hanafi, A., 1970, Pengantar dan Sejarah Hukum Islam, Jakarta: Bulan Bintang

Sjadzali, Munawir. 1993. Islam dan Tata Negara (Ajaran, Sejarah Dan Pemikiran). Jakarta: UI Press.

Tanpa Pengarang. 2010. The Common and Civil Law Tradition, Oxford: The Robbins Collection (Educational use only).

Tim Penyusun, 2002, Islam Untuk Disiplin Ilmu Hukum, Jakarta: Ditjen Kelembagaan Agama Islam, Departemen Agama 